\title{
$\sum \pi$
}

АНАЛІЗ ЧАСТОТИ ПОЛІМОРФІЗМУ ГЕНІВ ФОЛАТНОГ
ЦИКЛУ В ЖІНОК ІЗ РІЗНИХ РЕГІОНІВ УКРАЇНИ: ВЛАСНЕ ДОСЛІДЖЕННЯ ТА ОГЛЯД

\section{ВСТУП}

Вагітність - це складний багатоетапний процес, в якому виділяють декілька критичних періодів: запліднення, імплантація, органогенез, формування основних функціональних систем організму та плацентація. Зазвичай вагітність $\epsilon$ гіперкоагуляційним станом за рахунок посилення синтезу факторів згортання, зменшення рівнів антикоагулянтів та дефіциту фібринолізу. Хронічне невиношування вагітності (HB) $\epsilon$ важливою клінічною проблемою $з$ етіологією різного ґенезу і фактично може вважатись мультифакторним захворюванням. Поряд із несприятливою дією факторів оточуючого середовища в патогенезі НВ важливу роль відіграє спадкова схильність. Можливими причинами НB можуть бути генетичні, анатомічні, ендокринні та інфекційні захворювання, а також імунні дефекти. Ще однією причиною може бути мутація генів тромбофілії, з якою, за даними низки авторів [35, 36], може бути пов'язана повторна невдала імплантація.

Хронічне НВ визначається як втрата двох або більше послідовних вагітностей до 20-го тижня $[17,21,26]$. Подібний стан виявляється приблизно у $1 \%$ подружніх пар. Повторна невдала імплантація визначається як відсутність настання вагітності після сумарного переносу 10 ембріонів хорошої якості в циклах екстракорпорального запліднення (ЕК3) [24].

Виявлення поліморфізмів у генах, які відповідають за функціонування систем згортання крові, метаболізму фолатів, а також генів-регуляторів кров'яного тиску відіграють важливу роль в діагностиці, профілактиці й лікуванні мультифакторних захворювань в акушерстві та гінекології. Подібне тестування дозволяє прогнозувати ті чи інші порушення перебігу вагітності ще до появи клінічних ознак загрози їі переривання.

Фолатний цикл $\epsilon$ складним каскадним процесом, контрольованим ферментами, що мають за коферменти похідні фолієвої кислоти (ФК). Однією з реакцій цього процесу $\epsilon$ синтез метіоніну з гомоцистеїну (шлях реметилювання в обміні гомоцистеїну) [13]. Фермент метіонін-синтаза (MTR) забезпечує перетворення гомоцистеїну на метіонін завдяки реакції, в якій метилкобаламін (похідне вітаміну В12) виступає в ролі проміжного транспортера метильної групи. При цьому відбувається окислення кобаламіну, і фермент MTR переходить в неактивний стан. Відновлення функції ферменту можливе під час реакції метилювання за участю ферменту метіонін-синтази-редуктази (MTRR). Ключову ж роль у синтезі метіоніну з гомоцистеїну відіграє фермент 5,10-метилентетрагідрофолатредуктаза (MTHFR). Ген, який кодує MTHFR, знаходиться в хромосомній області 1p36.3. MTHFR бере участь у синтезі 5-метилентетрагідрофолату, який $\epsilon$ кофактором у ферментативному синтезі метіоніну 3 гомоцистеїну і тому відіграє вирішальну роль у ранньому ембріональному розвитку. Внаслідок поліморфізму MTHFR C677->T амінокислота аланін замінюється на валін, що призводить до зниження активності кодованого ферменту при $37^{\circ} \mathrm{C}$ або більше [16]. Більшість досліджень показують зв'язок цього поліморфізму з хронічним НВ у жінок та порушенням імплантації [5]. Повідомлялося про поширеність низькофункціональних алелей MTHFR в поєднанні з різними мутаціями генів схильності до тромбофілії в парах із НВ у порівнянні 3

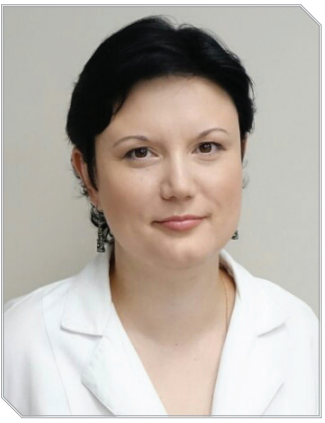

0.А. ФЕСАЙ

біолог Медичного центру ТОВ «Родинне джерело», м. Київ ORCID: 0000-0002-2129-5392

Г.В. СТРЕЛКО к. мед. н., лікар акушер-гінеколог вищої категорії, репродуктолог, головний лікар МЦ ТОВ «Родинне джерело», м. Київ

Г.В. ЗАЙЧЕНКО

д. мед. н., професор, завідувачка кафедрою фармакології

Національного медичного університету ім. 0.0. Богомольця

В.В. УЛАНОВА

лікар акушер-гінеколог вищої категорії, репродуктолог МЦ ТОВ «Родинне джерело», м. Київ

Контакти: Фесай Ольга Анатоліївна Медичний центр ТОВ «Родинне джерело» 03186, Київ, авіаконструктора Антонова 2-Б

Тел.: +38 (067) 7577077 ; +38 (073) 4811630 e-mail: olga_fesay@ukr.net 
контролем [8, 30]. Дефіцит ферменту MTHFR сприяє не тільки тератогенній (яка пошкоджує плід), але й мутагенній (яка пошкоджує ДНК) дії [15] (рис. 1).

Виникнення дефіциту ФК та вітамінів групи B, а також низькофункціональні алелі генів фолатного циклу можуть призводити до надлишкового накопичення гомоцистеїну (гіпергомоцистеїнемія) в крові та порушення процесів метилювання в клітині [13].

Гіпергомоцистеїнемія обумовлює ризик порушень розвитку хоріона та децидуальної тканини i, як наслідок, порушень процесів імплантації та плацентації (табл. 1). ФК коригує виникнення гіпергомоцистеїнемії під час вагітності та передгравідарної підготовки, що дозволяє знизити або навіть уникнути ризику розвитку таких патологічних станів, як гіперкоагуляція, окисний стрес, порушення процесів метилювання, дефекти розвитку центральної нервової системи (ЦНС) в ембріона, відшарування плаценти, затримка внутрішньоутробного розвитку, порушення процесів імплантації та плацентації [12].

MTHFR $\epsilon$ важливим ферментом для метаболізму ФК. Тому недостатність ФК або дефекти у MTHFR продемонстрували гіпометилювання ДНК й аномальні біохімічні та/або фенотипічні зміни на моделях тварин [27, 22], клітинної культури $[23,26]$ і в людини $[14$, $19,26,28,34]$.
Серед усіх генів фолатного циклу найкраще вивчений ген MTHFR. Maбуть, це пов'язано ще й з тим, що добре описаний взаємозв'язок поліморфізму С667->Т з венозними та артеріальними тромбозами, ризик розвитку яких особливо зростає в гомозигот за низькофункціональним алелем [20, 25], а це може призвести, наприклад, до порушень імплантації або плацентації. Однак не менш важливими для прогнозу перебігу вагітності $\epsilon$ генотипи за генами MTRR та MTR. Було показано вплив поліморфних варіантів цих генів (в комплексі з MTHFR) на розвиток самовільного переривання вагітності, до того ж найбільш негативний ефект дає поєднання низькофункціональних алелей одразу в декількох генах фолатного циклу [4].

Внесок поліморфізмів генів фолатного циклу у підвищення ризику виникнення НВ може бути обумовлений участю фолатів у багатьох життєво важливих клітинних процесах, в тому числі біосинтезі пуринових та піримідинових основ, метилюванні ДНК та iн. Поліморфізми генів фолатного циклу в різних комбінаціях можуть підвищувати ризик розвитку порушень плацентарного кровообігу, а також дозволяють прогнозувати схильність до гіпергомоцистеїнемії [3].

Метою даного дослідження було проаналізувати частоту генотипів поліморфізмів генів MTHFR, MTRR та MTR

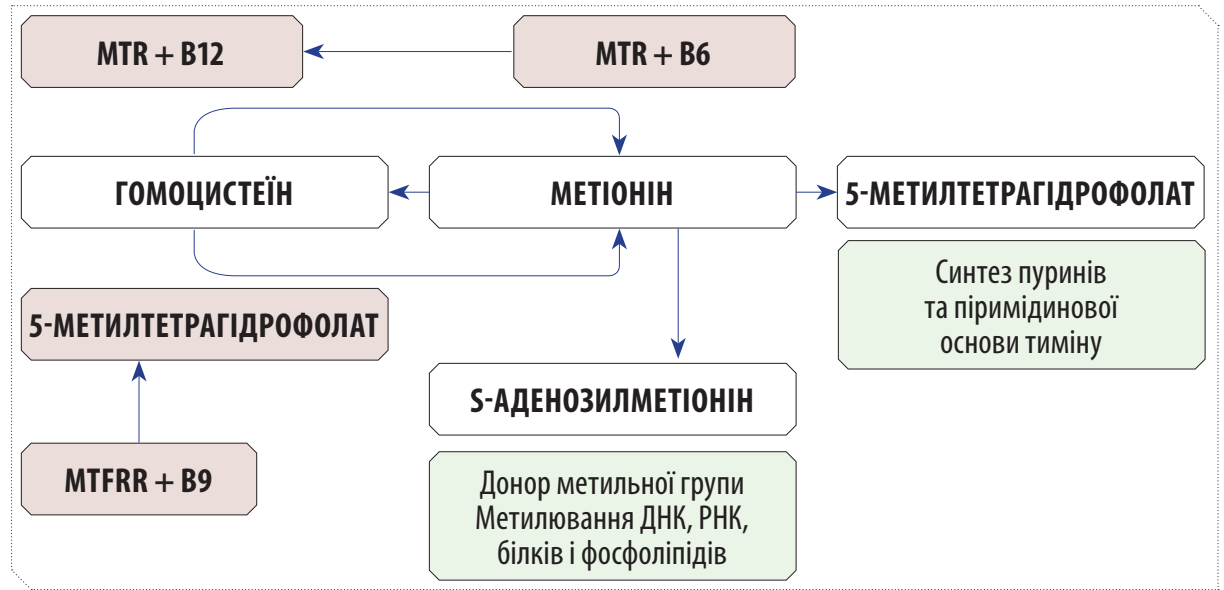

Рисунок 1. Схематичне зображення процесів фолатного циклу

\begin{tabular}{|c|c|c|}
\hline Таблиця 1. Вплив поліморфних варіантів генів фолатного циклу і ангіогенезу при завмерлій вагітності \\
\hline Поліморфні варіанти генів фолатного циклу & \multicolumn{2}{|c|}{ Ефект поліморфнних варіантів генів } \\
\hline MTHFR 677C->T & Мікротромбози в спіральних артеріях & Порушення імплантації \\
\hline MTHFR 1298A->C & Порушення проліферації & Невиношування \\
MTRR 66A->G & ендотелію судин плаценти, & вагітності \\
MTR 2756A->G & активація апоптозу клітин & \\
\hline
\end{tabular}

в популяції жінок із хронічним НВ у порівнянні з контрольною популяцією (умовно здорові жінки зі сприятливим акушерським анамнезом); узагальнити власні та інші українські дані стосовно частоти генотипів поліморфізмів генів MTHFR, MTRR та MTR в популяції жінок із хронічним НB; проаналізувати вплив низькофункціональних алелей генів фолатного циклу на процеси, пов'язані з перебігом вагітності.

\section{МАТЕРІАЛИ I МЕТОДИ ДОСЛІДЖЕННЯ}

Для вивчення розповсюдженості поліморфних варіантів генів фолатного циклу було проаналізовано 53 пацієнтки МЦ ТОВ «Родинне джерело» (Київ) із HB, які мали один або більше спонтанних викиднів та/або завмерлих/регресуючих вагітностей в акушерсько-гінекологічному анамнезі, а також 24 умовно здорові жінки (зі слів жінок) зі сприятливим акушерським анамнезом (відсутність самовільних викиднів, ускладнень вагітностей та пологів), які склали контрольну групу 1. Як контрольну групу 2 було використано групу порівняння з дослідження колег із ДУ «Інститут спадкової патології НАМН України» (м. Львів) - 150 жінок Західного регіону України без ускладненого генетичного та акушерського анамнезу, які мали двох та більше здорових дітей [1]. Групи були схожі за основними демографічними характеристиками.

Обстеження групи дослідження та контрольної групи 1 проводили в МЦ ТОВ «Родинне джерело» згідно зі стандартизованим протоколом, ДНК зі зразків венозної крові виділяли за допомогою наборів innuPREP Blood DNA Mini Kit (AnalytikJena, Німеччина). Забір венозної крові та виділення ДНК у контрольної групи 2 проводили в ДУ «Інститут спадкової патології НАМНУ», Львівському міжобласному медико-генетичному центрі та Закарпатському міжобласному медико-генетичному центрі за запатентованим авторами методом [1].

Молекулярно-генетичний аналіз генотипів генів MTHFR, MTRR та MTR у групи дослідження та контрольної групи 1 проводили методами стандартної полімеразної ланцюгової реакції (ПЛР) з використанням термоциклера 
SimpliAmp ${ }^{\text {TM }}$ Thermal Cycler A24811 (Life Technologies, США) та рестрикційного аналізу з подальшим детектуванням шляхом горизонтального електрофорезу в $2 \%$ агарозному гелі за допомогою системи для горизонтального електрофорезу в реальному часі runVIEW (Cleaver Scientific, Великобританія). Для контрольної групи 2 колеги використовували ампліфікацію послідовностей ДНК in vitro методом ПЛР, олігонуклеотидні праймери, ендонуклеази рестрикції та термостабільну Таq-полімеразу (Fermentas, Литва). Генотипування поліморфних локусів C677-> Т та А1298->C гена MTHFR, A2756->G гена MTR та A66->G гена MTRR проводили методом поліморфізму довжин рестрикційних фрагментів. Електрофорез проводили у 2,5\% агарозному гелі та сканували на УФ-трансілюмінаторі [1]. Тобто методика дослідження та використане обладнання були подібними в усіх групах.

Статистичну обробку результатів проводили з використанням онлайн-калькуляторів для розрахунку даних в медичній статистиці (http://medstatistic.ru/calculators.html), 30крема калькулятора розрахунку відношення шансів http:// medstatistic.ru/calculators/calcodds.html.

Оцінку різниці в розподілі поліморфних варіантів генів у досліджуваних групах здійснювали за критерієм $\chi^{2}$. Ризик розвитку НВ розраховували за формулою для відношення шансів (ВШ), вказуючи його з 95\% довірчим інтервалом (ДІ).

Дослідження були проведені у відповідності до принципів та норм біоетики та з інформованої згоди обстежених осіб.

\section{РЕЗУЛЬТАТИ ДОСЛІДЖЕННЯ}

У дослідженні було виявлено значний відсоток жінок (досліджувана група, $\mathrm{n}=53$ ) з низькофункціональними алелями в одному, декількох або усіх генах MTHFR, MTRR та MTR 83\% (44 з 53 пацієнток).

Розподіл генотипів досліджуваних генів фолатного циклу у групі жінок із НВ та двома контрольними групами наведено у таблиці 2.
Достовірно значущі результати було отримано при порівнянні гомозигот G/G гена MTRR в групі жінок із $\mathrm{HB}(\mathrm{n}=$ 53) та контрольною групою 2 ( $n=150)$ : ВШ 0,226 (95\% ДІ 0,099-0,517, p < 0,05), а також при порівнянні генотипів низькофункціональних алелей (A/G + G/G) гена MTR в групі жінок з НВ та контрольною групою 1 ( $\mathrm{n}=24)$ : ВШ 2,935 (95\% ДІ 1,044-8,245, p < 0,05). В усіх інших випадках статистично вірогідної відмінності виявлено не було. Але відсоток низькофункціональних алелей (C/T + T/T) гена MTHFR в досліджуваній групі був вищим, ніж в контрольних групах $1 \mathrm{i}$ 2 - 54,7, 41,7 та 46\% відповідно.

Цікаво відзначити, що в 60,4\% (32 з 53) жінок із НВ, окрім низькофункціональних алелей досліджуваних генів фолатного циклу, також виявляли мутантні алелі в генах схильності до тромбофілії та ендотеліальної дисфункції, що свідчить на користь мультифакторності патологічних станів при НВ.

Із 53 учасниць обстеженої групи підтверджена УзД вагітність настала у 25 випадках $(47,2 \%)$.

\section{ОБГОВОРЕННЯ РЕЗУЛЬТАТІВ ДОСЛІДЖЕННЯ}

За останні роки було проведено багато молекулярно-генетичних досліджень, в яких відмічався вплив або асоціація алелів, що обумовлюють знижену активність ензимів, генів MTHFR, MTRR, MTR у жінок із HB, фетоплацентарною недостатністю, пізнім гестозом, передчасним відшаруванням нормально розташованої плаценти, незарощенням нервової трубки плода, аненцефалією, деформацією лицьового скелету, народженням дітей із хромосомною патологією [2], вродженими вадами серця, екстремально низькою масою тіла [7].

У таблиці 3 наведено дані з розподілу частоти генотипів цих генів в українській популяції, які були описані різними групами вітчизняних авторів [1, 8, 9, 11, 32].

Як видно з таблиці 3, найбільш дослідженою в Україні $\epsilon$ популяційна частота поліморфних варіантів локусу C677->T, середня частота його низькофункціональних поліморфізмів

Таблиця 2. Розподіл генотипів генів MTHFR, MTRR i MTR серед жінок із НВ та в групах контролю, абс. ч. (\%)

\begin{tabular}{|c|c|c|c|}
\hline Генотип & 0бстежувана група ( $=53$ ) & Контрольна група 1 ( = 24) & Контрольна група 2 ( $=150)$ \\
\hline \multicolumn{4}{|c|}{ MTHFR } \\
\hline C/С (гомозиготи за нормальними алелями) & $24(45,3)$ & $14(58,3)$ & $82(54)$ \\
\hline С/Т (гетерозиготи за нормальними та низькофункціональними алелями) & $27(50,9)$ & $8(38,33)$ & $60(41)$ \\
\hline Т/Т (гомозиготи за низькофункціональними алелями) & $2(3,8)$ & $2(8,33)$ & $8(5)$ \\
\hline $\mathrm{C} / \mathrm{T}+\mathrm{T} / \mathrm{T}$ & $29(54,7)$ & $10(41,7)$ & $68(46)$ \\
\hline \multicolumn{4}{|c|}{ MTRR } \\
\hline A/A (гомозиготи за нормальними алелями) & $30(56,6)$ & $10(41,7)$ & $38(26)$ \\
\hline A/G (гетерозиготи за нормальними та низькофункціональними алелями) & $13(24,5)$ & $9(37,5)$ & $56(37)$ \\
\hline G/G (гомозиготи за низькофункціональними алелями) & $10(18,9)$ & $5(20,8)$ & $56(37)$ \\
\hline$A / G+G / G$ & $23(43,4)$ & $14(58,3)$ & $112(74)$ \\
\hline \multicolumn{4}{|c|}{ MTR } \\
\hline A/A (гомозиготи за нормальними алелями) & $24(45,3)$ & $17(70,8)$ & $64(43)$ \\
\hline A/G (гетерозиготи за нормальними та низькофункціональними алелями) & $19(35,8)$ & $7(29,2)$ & $58(39)$ \\
\hline G/G (гомозиготи за низькофункціональними алелями) & $10(18,9)$ & $0(0)$ & $28(18)$ \\
\hline$A / G+G / G$ & $29(54,7)$ & $7(29,2)$ & $86(57)$ \\
\hline
\end{tabular}


МІЖДИСЦИПЛІНАРНІ ПРОБЛЕМИ

Таблиця 3. Популяційні частоти поліморфних варіантів C677->T, A66-> G та A2756-> з за даними з різних регіонів України

\begin{tabular}{|c|c|c|c|c|c|c|c|c|c|c|c|}
\hline \multirow{2}{*}{ Локус } & \multirow{2}{*}{ Генотип } & \multicolumn{10}{|c|}{ Кількість обстежених осіб (n) та частота носіїв (\%) } \\
\hline & & $n^{1}$ & $\%^{1}$ & $n^{2}$ & $\%^{2}$ & $n^{3}$ & $\%^{3}$ & $n^{4}$ & $\%^{4}$ & $n^{5}$ & $\%^{5}$ \\
\hline \multirow{4}{*}{ MTHFR C677->T } & С/С (гомозиготи за нормальними алелями) & \multirow{4}{*}{96} & 45,8 & \multirow{4}{*}{200} & 52,26 & \multirow{4}{*}{172} & 49,4 & \multirow{4}{*}{100} & 38 & \multirow{4}{*}{150} & 54 \\
\hline & $\begin{array}{c}\text { C/Т (гетерозиготи за нормальними та } \\
\text { низькофункціональними алелями) }\end{array}$ & & 43,8 & & 40,7 & & 43 & & 52 & & 41 \\
\hline & $\begin{array}{c}\text { T/Т (гомозиготи за низькофункціональними } \\
\text { алелями) }\end{array}$ & & 10,4 & & 7,04 & & 7,6 & & 10 & & 5 \\
\hline & $\mathrm{C} / \mathrm{T}+\mathrm{T} / \mathrm{T}$ & & 54,2 & & 47,74 & & 50,6 & & 62 & & 46 \\
\hline \multirow{4}{*}{ MTRR A66->G } & A/А (гомозиготи за нормальними алелями) & \multirow{4}{*}{-} & - & \multirow{4}{*}{200} & 21,5 & & - & \multirow{4}{*}{-} & - & \multirow{4}{*}{150} & 26 \\
\hline & $\begin{array}{c}\text { A/G (гетерозиготи за нормальними та } \\
\text { низькофункціональними алелями) }\end{array}$ & & - & & 43,0 & & - & & - & & 37 \\
\hline & $\begin{array}{c}\text { G/G (гомозиготи за } \\
\text { низькофункціональними алелями) }\end{array}$ & & - & & 35,5 & & - & & - & & 37 \\
\hline & $A / G+G / G$ & & - & & 78,5 & & - & & - & & 74 \\
\hline \multirow{4}{*}{ MTR A2756->G } & A/A (гомозиготи за нормальними алелями) & \multirow{4}{*}{ - } & - & \multirow{4}{*}{ - } & - & & - & \multirow{4}{*}{ - } & - & \multirow{4}{*}{150} & 43 \\
\hline & $\begin{array}{l}\text { A/G (гетерозиготи за нормальними та } \\
\text { низькофункціональними алелями) }\end{array}$ & & - & & - & & - & & - & & 39 \\
\hline & $\begin{array}{c}\text { G/G (гомозиготи за } \\
\text { низькофункціональними алелями) }\end{array}$ & & - & & - & & - & & - & & 18 \\
\hline & $A / G+G / G$ & & - & & - & & - & & - & & 57 \\
\hline \multicolumn{4}{|c|}{$\begin{array}{l}\text { ' дослідження } 2006 \text { року - різні регіони України [11]; } \\
2 \text { дослідження } 2010 \text { року - переважно Харківська область [8]; } \\
\text { 3 дослідження } 2010 \text { року - різні регіони України [32]; }\end{array}$} & \multicolumn{8}{|c|}{$\begin{array}{l}{ }^{4} \text { дослідження } 2011 \text { року - центральна частина України [9]; } \\
{ }^{5} \text { дослідження } 2011 \text { року - західноукраїнський регіон [1]. }\end{array}$} \\
\hline
\end{tabular}

(C/T + T/T), за даними з різних регіонів України, складає 50,9\%. Тобто, можна припустити, що кожна друга жінка в Україні має низькофункціональні алелі генів фолатного циклу та відповідно проблеми із засвоюванням організмом фолатів.

Так, у дослідженні 2011 року [1] як контрольну групу було обрано вагітних жінок без патологій (умовно здорові жінки зі сприятливим акушерсько-гінекологічним анамнезом та історією народження двох та більше дітей), в яких алелі зі зниженою активністю ензиму гена MTHFR переважно зустрічались в гетерозиготному стані (52\%) (див. табл. 2). Трохи меншим був відсоток таких алелей у дослідженні 2010 року [8] - 47,74\%.

В роботі колег із західноукраїнського регіону було досліджено поліморфні варіанти саме трьох генів фолатного циклу серед груп жінок із НВ та контрольною групою жінок без обтяженого акушерського анамнезу (табл. 4) [1].

У дослідженні наших колег при аналізі поліморфного локусу MTR A2756-> G було показано, що генотип із низькофункціональним алелем (G/G) статистично вірогідно частіше зустрічався в контрольній групі жінок, ніж у групі жінок із НB (28 проти 6). Автори припускають, що даний поліморфний варіант не чинить значного впливу на розвиток $\mathrm{HB}, \mathrm{a}$, можливо, й відіграє протекторну роль [1].

Таблиця 4. Розподіл генотипів генів MTHFR, MTRR i MTR серед жінок із HВ та в контрольній групі (Західний регіон України)

\begin{tabular}{|c|c|c|c|c|c|}
\hline \multirow{2}{*}{ Локус } & \multirow{2}{*}{ Генотип } & \multicolumn{2}{|c|}{ Жінки 3 HB ( $(n=84)$} & \multicolumn{2}{|c|}{ Контрольна група ( $=150)$} \\
\hline & & $\mathbf{n}$ & $\%$ & $\mathbf{n}$ & $\%$ \\
\hline \multirow{4}{*}{ MTHFR C677->T } & C/C (гомозиготи за нормальними алелями) & 40 & 48 & 82 & 54 \\
\hline & С/Т (гетерозиготи за нормальними та низькофункціональними алелями) & 32 & 38 & 60 & 41 \\
\hline & Т/Т (гомозиготи за низькофункціональними алелями) & 12 & 14 & 8 & 5 \\
\hline & $C / T+T / T$ & 44 & 52 & 68 & 46 \\
\hline \multirow{4}{*}{ MTRR A66->G } & A/A (гомозиготи за нормальними алелями) & 8 & 10 & 38 & 26 \\
\hline & A/G (гетерозиготи за нормальними та низькофункціональними алелями) & 42 & 50 & 56 & 37 \\
\hline & G/G (гомозиготи за низькофункціональними алелями) & 34 & 40 & 56 & 37 \\
\hline & $A / G+G / G$ & 76 & 90 & 112 & 74 \\
\hline \multirow{4}{*}{ MTR A2756->G } & A/A (гомозиготи за нормальними алелями) & 50 & 60 & 64 & 43 \\
\hline & A/G (гетерозиготи за нормальними та низькофункціональними алелями) & 28 & 33 & 58 & 39 \\
\hline & G/G (гомозиготи за низькофункціональними алелями) & 6 & 7 & 28 & 18 \\
\hline & $A / G+G / G$ & 34 & 40 & 86 & 57 \\
\hline
\end{tabular}


Наше дослідження також свідчить на користь цієї гіпотези, оскільки відсотки нормальних алелей перевищують відсотки низькофункціональних алелей у досліджуваній групі та контрольній групі 2 (див. табл. 2). В контрольній групі 1 ця тенденція на рівні відсотків поки що не спостерігається, швидше за все, через малу кількість обстежених осіб (24). Але вірогідність розвитку патології у групі жінок із НВ в порівнянні з контрольною групою 1 знижується майже в 3 рази (ВШ 2,935, 95\% ДІ 1,044-8,245, p < 0,05). Окрім того, серед 25 підтверджених вагітностей 14 (56\%) відзначено в жінок із низькофункціональними алелями гена MTR.

Також однією з причин НВ у першому триместрі $\epsilon$ наявність геномних мутацій у плода, виникнення яких в більшості випадків обумовлено нерозходженням хромосом у гаметогенезі в батьків. Тому доцільно також враховувати дослідження поліморфних варіантів генів фолатного циклу в чоловіків [18, 30]. Хронічний дефіцит ФК у чоловіків може проявляти себе у вигляді безпліддя та мегабластної анемії [31]. При зниженні концентрації фолатів синтез сперматозоїдів порушується, зменшується їх концентрація та погіршується морфологія. Було показано, що в чоловіків із високим вмістом анеуплоїдних сперматозоїдів в еякуляті частоти генотипів із низькофункціональними алелями генів фолатного циклу в 2-4 рази вище, ніж у чоловіків із порушеннями фрагментації ДНК [2]. Вчені розглядають також необхідність прийому фолатів чоловіками фертильного віку: високий вміст споживання вітаміну В9 (ФК) співвідноситься з меншим відсотком анеуплоїдії сперматозоїдів [7]. 3 огляду на це в клініці «Родинне джерело» для діагностики генетичної складової чоловічого безпліддя до пакету ДНК-діагностики включено дослідження поліморфізмів генів фолатного циклу.

Гомоцистеїн синтезується з метіоніну шляхом трансметиленових реакцій в присутності кофакторів - вітамінів В6 та В12 і ФК як субстрату за участю ферментів цистатіон-ß-синтази та MTHFR. При дефіциті фолатів рівні гомоцистеїну в плазмі та еритроцитах крові зростають [6]. Високий вміст гомоцистеїну призводить до гіперкоагуляції, окисного стресу, порушення процесів метилювання, крім того, гіпергомоцистеїнемія може призводити до дефектів розвитку ЦНС в ембріона, відшарування плаценти, затримки внутрішньоутробного розвитку, а також обумовлює ризик порушень розвитку хоріона та децидуальної тканини і, як наслідок, порушень процесів імплантації та плацентації.

Профілактикою та корекцією виникнення гіпергомоцистеїнемії під час вагітності й в передгравідарній підготовці $\epsilon$ додавання до раціону ФК. Згідно з наказом МO3 України, рекомендується щоденний прийом 400 мкг ФК до настання вагітності та в їі ранні терміни (до 12 тижнів) для профілактики вад розвитку ЦНС плода. За показаннями лікар може підвищити дозування ФК [10]. Оскільки в осіб із низькофункціональними алелями генів фолатного циклу вона погано засвоюється, необхідно використовувати вітамінні комплекси, в яких ФК матиме метаболічно активну форму - метафолін.

Фолат (водорозчинний вітамін В9) - синтетична неметильована форма ФК, яка міститься у дієтичних добавках. Синтетична ФК метаболізується в організмі в левомефолієву кислоту (5-метилтетрагідрофолат) (рис. 2).

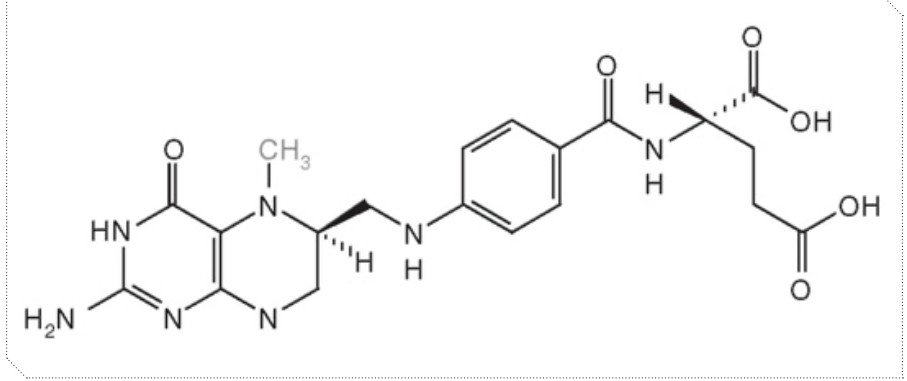

Рисунок 2. Молекула 5-метилтетрагідрофолату

У носіїв гомозиготних (Т/Т) низькофункціональних алелей гена MTHFR в організмі не вистачає ферментів, необхідних для перетворення ФК на активну форму. Гетерозиготні носії (C/T) низькофункціональних алелей гена MTHFR здатні перетворювати на 5-метилтетрагідрофолат лише обмежену кількість ФК.

Метафолін не потребує перетворення, оскільки це активна метильована форма ФК (рис. 3).

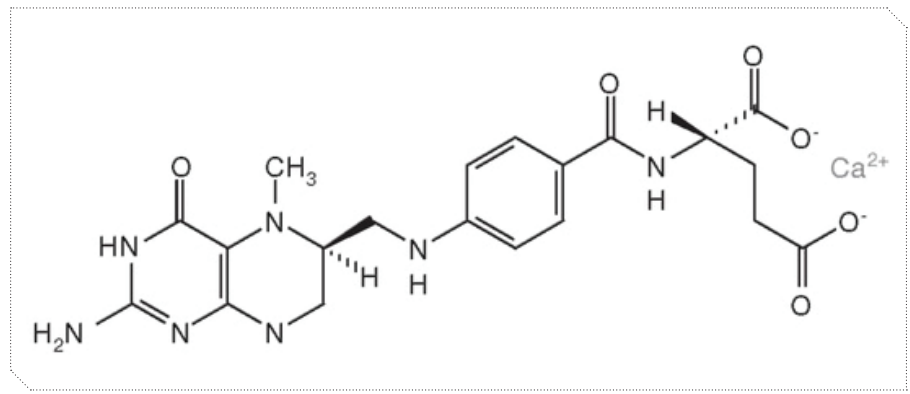

Рисунок 3. Молекула метафоліну

Метафолін (кальцієва сіль L-5-метилтетрагідрофолієвої кислоти) - молекула, ідентична фолатам, які містяться в харчових продуктах та організмі людини, розроблена в Німеччині та комерційно представлена компанією MERCK. Ця активна форма речовини має високу біодоступність та не маскує симптоми В12-дефіцитної анемії [29].

На сьогодні в Україні зареєстровані препарати, які містять ФК і пропонуються виробниками для нормалізації гормонального фону, відновлення фертильної функції як у жінок, так і у чоловіків, коригування різних патологічних станів при синдромі полікістозних яєчників тощо. Також зараз ФК почали додавати до оральних контрацептивів нового покоління та середовища для культивування ембріонів.

Метафолін - основний компонент фолатовмісних комплексів Фемібіон Наталкер I та Фемібіон Наталкер II (для жінок, що планують вагітність, вагітних та жінок, які годують), що диференціює їх від препаратів, які містять ФК. Фемібіон Наталкер I та Фемібіон Наталкер II містять 400 мкг фолатів (ФК та метафоліну в рівних пропорціях) [7], що відповідає рекомендаціям MO3 [10]. Метафолін засвоюється організмом незалежно від генетичних варіантів фолатоперетворюючих ферментів, а отже $\epsilon$ препаратом вибору для профілактики та корекції фолатодефіцитних станів за умови розповсюдженості поліморфізму фолатних генів в українській популяції. 


\section{ВИСНОВКИ}

1. Згідно з результатами об'єднаного аналізу, в субпопуляціях із різних регіонів України переважають генотипи з низькофункціональними алелями. Найбільш дослідженою є популяційна частота поліморфних варіантів гена MTHFR C677->T, середня частота його низькофункціональних поліморфізмів (C/T + T/T), за даними з різних регіонів України, складає 50,9\%. Тобто можна припустити, що в кожної другої української жінки репродуктивного віку фолати не перетворюються в активну форму і не засвоюються організмом достатньою мірою.

2. Досліджена частота генотипу 3 низькофункціональними алелями гена MTHFR для групи жінок із HB склала 54,7\%, що корелює з прогнозованою частотою в популяції українських жінок.

3. Очікувана частота генотипу з низькофункціональними алелями гена MTRR для групи жінок із HB склала 43,4\%, що менше за прогнозовану частоту в загальній популяції (58,3-78,5\%). Це можна пояснити малою кількістю власної вибірки жінок обстеженої групи (53 особи).

4. Частота генотипу з низькофункціональними алелями гена MTR у дослідженій групі жінок із НВ склала 54,7\%, що приблизно збігається з прогнозованою частотою в популяції (до 57\%).

5. Наразі недостатньо опублікованих даних для висновку щодо частоти генотипу з низькофункціональними алелями гена MTRR в популяції українських жінок як в ізо- льованому вигляді, так і в комбінаціях із низькофункціональними алелями генів MTHFR та/або MTR.

6. Поширеність і механізми успадкування даних поліморфізмів, їхній потенційний вплив на процеси імплантації та ембріогенезу свідчать про необхідність обстеження на наявність цих низькофункціональних алелей не тільки жінки, але й чоловіка (в клініці «Родинне джерело» для діагностики генетичної складової чоловічого безпліддя до пакета ДНК-діагностики включено дослідження поліморфізмів генів фолатного циклу).

7. Дослідження доводить важливість проведення обстеження подружніх пар, що страждають на безпліддя, мають НВ або планують вагітність, на наявність поліморфізмів генів MTHFR, MTRR та MTR фолатного циклу.

8. Сучасні біодоступні форми фолатів, такі як у складі засобів Фемібіон Наталкер I та Фемібіон Наталкер II, містять 400 мкг фолатів (ФК і метафолін в рівних пропорціях), що відповідає рекомендаціям МО3 України та дозволяє рекомендувати їх як оптимальні для ефективного персоналізованого підбору дозування фолатовмісні комплекси, які забезпечують підтримання необхідного рівня фолатів під час підготовки до вагітності та виношування дитини.

9. Враховуючи вищеозначене, дослідження частоти генотипів низькофункціональних алелей генів фолатного циклу в українській жіночій популяції репродуктивного віку потребує подальшого комплексного вивчення.

\section{ЛITEPATYPA/REFERENCES}

1. Чорна, Л.Б.

Аналіз поліморфних варіантів генів MTHFR, MTR, MTRR та мутацій генів FV та FII згортання крові серед жінок з навиковим невиношуванням вагітності / Л.Б. Чорна, Г.В. Макух, Г.Р. Акопян та ін. // Вісник Харківського національного університету ім. В.Н. Каразіна. Серія: Біологія. - 2001. - Вип. 13, № 947. - С. 118-124. Chorna, L.B., Makukh, G.V., Akopyan, G.R., et al.

"Analysis of polymorphous variants of MTHFR, MTR, MTRR genes and FV and FII gene mutations in blood coagulation in women with miscarriage." Bulletin of V.N. Karazin Kharkiv National University. Series: Biology. 947 Issue 13 (2001): 118-24.

2. Жилкова, Е.С.

Анализ полиморфных вариантов генов MTHFR (C677T, А1298C) и

MTRR (A66G) у мужчин со сниженной репродуктивной функцией

/ Е.С. Жилкова, Н.Н. Сотник, А.М. Феськов, А.М. Федота // Вісник

проблем біології і медицини. - 2015. - Т. 2 (125), вип. 4. -

C. $253-258$

Zhilkova, E.S., Sotnik, N.N., Feskov, A.M., Fedota, A.M.

"Analysis of polymorphic variants of the MTHFR (C677T, A1298C) and

MTRR (A66G) genes in men with reduced reproductive function." Bulletin

of biological and medicinal problems 2.125 Issue 4 (2015): 253-8.

3. Машкина, Е.B.

Ассоциация полиморфных вариантов генов фолатного цикла и

интегринов с невынашиванием беременности / Е.В. Машкина,

К.А. Коваленко, Л.В. Гутникова и др. // Медицинская генетика. -

2013. - № 1. - C. 40-45

Mashkina, E.V., Kovalenko, K.A., Gutnikova, L.V., et al.

"Association of polymorphic variants of folate cycle genes and integrins with miscarriage." Medical Genetics 1 (2013): 40-5.

4. Бескоровайная, Т.C.

Влияние некоторых генетических факторов на нарушение

репродукции у человека: дис. канд. мед. наук / Т.С. Бескоровайная.

- M., 2005. -89 c.

Beskorovainaya, T.S.

The influence of some genetic factors on the violation of reproduction in humans. Thesis for PhD degree. Moscow (2005): 89 p.

5. Беспалова, $0 . \mathrm{H}$.

Генетика невынашивания беременности / 0.Н. Беспалова //

Журнал акушерства и женских болезней. - 2007. - Toм LVI,

вып. 1. - C. 81-95.

Bespalova, 0.N.

"Genetics of miscarriage." Journal of Obstetrics and Women's Diseases LVI Issue 1 (2007): 81-95.
6. Всемирная организация здравоохранения.

Оценка фолатного статуса у различных групп населения по концентрации фолата в сыворотке крови и красных кровяных клетках. Информационная система данных о содержании витаминов и минералов в продуктах питания. - Женева, В03. - 2012

World Health Organization.

Estimation of folate status in different groups of the population by the concentration of folate in blood serum and red blood cells. Information system of data on the content of vitamins and minerals in food. Geneva. WHO (2012). Available from: [http://www.who.int/iris/ bitstream/10665/75584/4/WHO_NMH_NHD_EPG_12.1_rus.pdf].

7. Зайченко, А.В.

Фолаты и омега-3-ПнЖК в акушерстве: больше чем профилактика дефектов нервной трубки / А.В. Зайченко // Здоров'я України, березень 2018. Тематичний номер. - С. 10-11.

Zaychenko, A.V.

"Folates and omega-3-PUFA in obstetrics: more than the prevention of neural tube defects." Health of Ukraine, thematic number (March 2018): $10-1$.

8. Гречанина, Е.Я

Закономерная связь между развитием некоторых эпигенетических болезней и нарушением метилирования ДНК вследствие дефицита ферментов фолатного цикла / Е.Я. Гречанина, В.Н. Лесовой,

B.В. Мясоедов // Ультразвукова перинатальна діагностика. -

2010. - № 29. - C. 27-59.

Grechanina, E.Y., Lesovoi, V.N., Myasoedov, V.V.

"The natural connection between the development of some epigenetic diseases and the violation of DNA methylation due to a deficiency of folate cycle enzymes." Ultrasound perinatal diagnostics 29 (2010):

27-59.

9. Вашукова, Е.C.

Исследование полиморфизма генов системы свертывания крови и фибринолиза у условно здоровых беременных России и Украины / Е.С. Вашукова, А.С. Глотов, М.Д. Канаева и др. // Экологическая генетика. - 2011. -Т. IX, № 1. - С. 70-80.

Vashukova, E.S., Glotov, A.S., Kanaeva, M.D., et al.

"Investigation of the polymorphism of blood clotting and fibrinolysis genes in conditionally healthy pregnant women in Russia and Ukraine." Ecological Genetics 1 Vol. IX (2011): 70-80.

10. Наказ М03 України № 417 від 15.07.2011.

«Про організацію амбулаторної акушерсько-гінекологічної допомоги в Україні».

Order of the MOH of Ukraine N No. 417 from 15.07.2011.

«About organization of ambulatory obstetric and gynecological care in Ukraine».
11. Марценюк, 0.П.

Поліморфізм генів метилентетрагідрофолатредуктази, глутатіонтрансфераз Р1, М1 і цитохрому 3450 1А1 та глутатіонтрансферазна активність у плаценті людини / 0.П. Марценюк, Л.Я. Сазонова, Ч. Мишланова, М.Ю. Оболенська // Біополімери і клітина. - 2006. - Т. 22, № 6. - С. 452-457. Marceniuk, O.P., Sazonova, L.Y., Mishlanova, Ch., Obolenska, M.Y. "Polymorphism of methylenetetrahydrofolate reductase genes, glutathione transfereases P1, M1 and cytochrome Z450 1A1 and glutathione transfected activity in human placenta." Biopolymers and cell 6 Issue 22 (2006): 452-7.

12. Тромбогеморрагические осложнения в акушерскогинекологической практике / Руководство для врачей. - М.: 000 «Медицинское информационное агенство», 2011. - 1056 c. Thrombohemorrhagic complications in obstetric-gynecological practice. Manual for doctors.

Moscow. Medical Information Agency Ltd (2011): 1056p.

13. Фетисова, И.Н.

Полиморфизм генов фолатного цикла и болезни человека / И.Н.

Фетисова // Вестник Ивановской медицинской академии. - 2006. T. 11, № 1-2. - C. 77-82.

Fetisova, I.N.

"Polymorphism of genes of folate cycle and human diseases." Bulletin of the Ivanovo Medical Academy 11.1-2 (2006): 77-82.

14. Friso, S., Choi, S.W., Girelli, D., et al.

"A common mutation in the 5,10-methylenetetrahydrofolate reductase gene affects genomic DNA methylation through an interaction with folate status." Proc Natl Acad Sci USA 99.8 (2002): 5606-11.

15. Van der Put, N.M., Gabreels, F., Stevens, E.M., et al.

"A second common mutation in the methylenetetrahydrofolate reductase gene: an additional risk factor for neural-tube defects?" Am J Hum Genet 62 (1998): 1044-51.

16. Weisberg, I., Tran, P., Christensen, B., et al.

"A second genetic polymorphism in methylenetetrahydrofolate reductase (MTHFR) associated with decreased enzyme activity." Mol Genet Metab 64 (1998): 169-72.

17. Branch, D.W., Gibson, M., Silver, R.M.

"Clinical practice. Recurrent miscarriage." N Engl J Med 363.18 (2010): 1740-7.

18. Jivraj, S., Rai, R., Underwood, J., et al.

"Genetic thrombophilic mutations among couples with recurrent miscarriage." Hum Reprod 21.5 (2006): 1161-5. 
19. Stern, L.L., Mason, J.B., Selhub, J., et al.

"Genomic DNA hypomethylation, a characteristic of most cancers, is present in peripheral leukocytes of individuals who are homozygous fo the C677T polymorphism in the methylenetetrahydrofolate reductase gene." Cancer Epidemiol Biomarkers Prev 9.8 (2000): 849-53.

20. Franchis, R Mangini, F D'Angelo, A et al.

"Elevated total plasma homocysteine and 677 CfiT mutation of 5 , 10-methylenetetrahydrofolate reductase gene in thrombotic vascular disease." Am J Hum Genet 59 (1996): 262-4.

21. Jauniaux, E. Farquharson, R.G. Christiansen, O.B., Exalto, N.

"Evidence-based guidelines for the investigation and medical treatment of recurrent miscarriage." Hum Reprod 21.9 (2006): 2216-22.

22. Kim, Y.I., Pogribny, I.P., Basnakian, A.G., et al.

"Folate deficiency in rats induces DNA strand breaks and

hypomethylation within the p53 tumor suppressor gene." Am J Clin Nutr

65.1 (1997): 46-52.

23. Duthie, S.J., Narayanan, S., Blum, S., et al.

"Folate deficiency in vitro induces uracil misincorporation and DNA

hypomethylation and inhibits DNA excision repair in immortalized normal

human colon epithelial cells." Nutr Cancer 37.2 (2000): 245-51.

24. Levi Setti, P.E., Colombo, G.V., Savasi, V., et al.

"Implantation failure in assisted reproduction technology and a critical

approach to treatment." Ann NY Acad Sci 1034 (2004): 184-99.

25. Keijzer, M.B.A.J., den Heijer, M., Blom, H.J., et al.

"Interaction between hyperhomocysteinemia, mutated methylenetetr ahydrofolatereductase (MTHFR) and inherited thrombophilic factors in

recurrent venous thrombosis." Thromb Hemost 88 (2002): 723-8.
26. Kimura, M., Umegaki, K., Higuchi, M., et al.

"Methylenetetrahydrofolate reductase (677T polymorphism, folic acid and riboflavin are important determinants of genome stability in cultured human lymphocytes."J Nutr 134.1 (2004): 48-56.

27. Chen, Z., Karaplis, A.C., Ackerman, S.L., et al.

"Mice deficient in methylenetetrahydrofolate reductase exhibit

hyperhomocysteinemia and decreased methylation capacity, with

neuropathology and aortic lipid deposition." Hum Mol Genet 10.5

(2001): 433-43.

28. Jacob, R.A., Gretz, D.M., Taylor, P.C., et al.

"Moderate folate depletion increases plasma homocysteine and decreases lymphocyte DNA methylation in postmenopausal women."

J Nutr 128.7 (1998): 1204-12.

29. Obeid, R., Holzgreve, W., Pietrzik, K.

"Is 5-methyltetrahydrofolate an alternative to folic acid for the prevention of neural tube defects?"J Perinat Med 41.5 (2013): 469-83.

30. Toth, B., Vocke, F., Rogenhofer, N., et al.

"Paternal thrombophilic gene mutations are not associated with

recurrent miscarriage." Am J Reprod Immunol 60.4 (2008): 325-32.

31. Ratanas Thien, K., Blair, J.A., Leeming, R.J., et al.

"Serum folates in man." J Clin Path 30 (1977): 438-48.

32. Tatarskyy, P., Kucherenko, A., Livshits, L.

"Allelic polymorphism of F2, F5 and MTHFR genes in population of

Ukraine." Cytology and genetics 3 (2010): 3-8.

33. Berry, C.W., Brambati, B., Eskes, T.K., et al.

"The Euro-Team Early Pregnancy (ETEP) protocol for recurrent

miscarriage." Hum Reprod 10.6 (1995): 1516-20.
34. Castro, R., Rivera, I., Ravasco, P., et al.

"5,10-methylenetetrahydrofolate reductase (MTHFR) $677(-->$ T and

1298A--> ( mutations are associated with DNA hypomethylation." J Med

Genet 41.6 (2004): 454-8.

35. Воробей-Вихівська, В.М

Роль системи гемостазу в результативності програм допоміжних

репродуктивних технологій : автореф. дис. канд. мед. наук

В.М. Воробей-Вихівська. - Київ, 2017. - 20 с.

Vorobey-Vykhivska, V.M.

"The role of the hemostasis system in the effectiveness of programs of auxiliary reproductive technologies."Thesis abstract for MD degree. Kyiv (2017): $20 \mathrm{p}$

36. Линников, В.И.

Клиническое значение выявления тромбофилии у пациенток с

бесплодием и неудачами экстракорпорального оплодотворения

В.И. Линников // Здоровье Женщины - 2015 - № 3 (99) - - C.

175-181.

Linnikov, V.I.

"Clinical significance of the detection of thrombophilia in patients with infertility and failure of in vitro fertilization."Women's Health 3.99 (2015): 175-81. i

\section{АНАЛІЗ ЧАСТОТИ ПОЛІМОРФІЗМУ ГЕНІВ ФОЛАТНОГО ЦИКЛУ В ЖІНОК ІЗ РІЗНИХ РЕГІОНІВ УКРАЇНИ: ВЛАСНЕ ДОСЛІДЖЕННЯ ТА ОГЛЯД}

0.А. Фесай, біолог Медичного центру ТОВ «Родинне джерело», м. Київ

Г.В. Стрелко, к. мед. н., лікар акушер-гінеколог вищої категорії, репродуктолог, головний лікар МЦ ТОВ «Родинне джерело», м. Київ

Г.В. Зайченко, д. мед. н., професор, зав. кафедрою фармакології Національного медичного університету ім. 0.0. Богомольця

В.В. Уланова, лікар акушер-гінеколог вищої категорії, репродуктолог МЦ ТОВ «Родинне джерело», м. Київ

Метою даного дослідження було проаналізувати частоту поліморфізму генів MTHFR, MTRR та MTR в популяції жінок із хронічним невиношуванням вагітності в порівнянні з контрольною популяцією; узагальнити українські дані стосовно частот генотипів поліморфізмів генів MTHFR, MTRR та MTR в популяції жінок з хронічним невиношуванням вагітності, а також в загальній жіночій популяції; проаналізувати вплив низькофункціональних алелів генів фолатного циклу на процеси, пов'язані з перебігом вагітності.

Для вивчення розповсюдженості поліморфних варіантів генів фолатного циклу було проаналізовано 53 пацієнтки медичного центру ТОВ «Родинне джерело» (Київ) із невиношуванням вагітності, які мали один або більше спонтанних викиднів та/або завмерлих/регресуючих вагітностей в акушерсько-гінекологічному анамнезі, а також 24 умовно здорові жінки зі сприятливим акушерським анамнезом (відсутність самовільних викиднів, ускладнень вагітностей та пологів), які склали контрольну групу 1. Як контрольну групу 2 було використано групу порівняння з дослідження ДУ «Інститут спадкової патології НАМН України» (м. Львів) - 150 жінок Західного регіону України без ускладненого генетичного та акушерського анамнезу, які мали двох та більше здорових дітей. Усі групи були схожі за основними демографічними характеристиками.

Результати і висновки. В дослідженні було виявлено значний відсоток жінок із низькофункціональними алелями в одному, декількох або усіх генах MTHFR, MTRR та MTR - 83\% (44 3 53 обстежених жінок основної групи). Порівняно частоти генотипів даних генів у пацієнток із невиношуванням вагітності та в групах популяційного контролю $з$ різних регіонів України. За даними з різних регіонів встановлено, що середня частота низькофункціональних поліморфних варіантів гена MTHFR С677-> Т складає більше 50\% в загальній жіночій популяції. Розглянуто зв'язок/асоціацію низькофункціональних алелів генів MTHFR, MTRR та MTR із порушеннями різних процесів, пов'язаних із перебігом вагітності.

Ключові слова: вагітність, невиношування вагітності, поліморфізм генів фолатного циклу, гіпергомоцистеїнемія, фолієва кислота, метафолін.

\section{АНАЛИЗ ЧАСТОТЫ ПОЛИМОРФИЗМА ГЕНОВ ФОЛАТНОГО ЦИКЛА У ЖЕНЩИН ИЗ РАЗНЫХ РЕГИОНОВ УКРАИНЫ: СОБСТВЕННОЕ ИССЛЕДОВАНИЕ И ОБЗОР}

0.А. Фесай, биолог МЦ 000 «Родинне джерело», г. Киев

Г.В. Стрелко, к. мед. н., врач акушер-гинеколог высшей категории, репродуктолог, главврач Мц 000 «Родинне джерело», г. Киев

А.В. Зайченко, д. мед. н., профессор, зав. кафедрой фармакологии НМУ им. А.А. Богомольца

B.В. Уланова, врач акушер-гинеколог высшей категории, репродуктолог МЦ 000 «Родинне джерело», г. Киев

Целью данного исследования был анализ частоты полиморфизма генов MTHFR, MTRR, MTR в популяции женщин с хроническим невынашиванием беременности по сравнению с контрольной популяцией; обобщение украинских данных относительно частоты полиморфизма генов MTHFR, MTRR и MTR в популяции женщин с хроническим невынашиванием беременности, а также в общей женской популяции; анализ влияния низкофункциональных аллелей генов фолатного цикла на процессы, связанные с течением беременности. Для изучения распространенности полиморфных вариантов генов фолатного цикла были проанализированы 53 пациентки медицинского центра 000 «Родинне джерело» (г. Киев) с невынашиванием беременности, у которых был один или более спонтанных выкидышей и/или замерших/регрессирующих беременностей в акушерско-гинекологическом анамнезе, а также 24 условно здоровые женщины с благоприятным акушерским анамнезом (отсутствие самопроизвольных выкидышей, осложнений беременностей и родов), которые составили контрольную группу 1. В качестве контрольной группы 2 была использована группа сравнения из исследования ГУ «Институт наследственной патологии НАМН Украины» (г. Львов) 150 женщин Западного региона Украины без осложненного генетического и акушерского анамнеза, которые имели двух и более здоровых детей. Все группы были схожи по основным демографическим характеристикам.

Результаты и выводы. В исследовании был выявлен значительный процент женщин с низкофункциональными аллелями в одном, нескольких или всех генах MTHFR, MTRR, MTR - 83\% (44 из 53 обследованных женщин основной группы). Проведено сравнение частоты генотипов данных генов среди пациенток с невынашиванием беременности и групп популяционного контроля из разных регионов Украины. По данным из разных регионов установлено, что средняя частота низкофункциональных полиморфных вариантов гена МТНFR С677-> составляет более 50\% в общей женской популяции. Рассмотрена связь/ассоциация низкофункциональных аллелей генов MTHFR, MTRR, MTR с нарушениями различных процессов, связанных с течением беременности.

Ключевые слова: беременность, невынашивание беременности, полиморфизм генов фолатного цикла, гипергомоцистеинемия, фолиевая кислота, метафолин.

\section{ANALYSIS OF FREQUENCIES OF POLYMORPHISM OF FOLATE-CYCLE GENES IN WOMEN FROM DIFFERENT REGIONS OF UKRAINE: OWN STUDY AND REVIEW}

0.A. Fesai, biologist at Medical centre "Family source" Ltd, Kyiv

G.V. Strelko, PhD, obstetrician gynecologist high category, reproductologist, head of Medical centre "Family source" Ltd, Kyiv

G.V. Zaychenko, MD, professor, head of pharmacology department, 0.0. Bogomolets National Medical University

V.V. Ulanova, obstetrician gynecologist high category, reproductologist at the Medical centre "Family source" Ltd, Kyiv

The aim of this study were to analyze prevalence of the polymorphism of the MTHFR, MTRR, MTR genes in women with chronic miscarriages compared with the control population; to generalize Ukrainian data about MTHFR, MTRR and MTR genes polymorphism prevalence in women with chronic miscarriages and in general women population; to analyze impact of low-functional alleles of folate-cycle genes on processes related to the pregnancy course.

To study the prevalence of polymorphic variants of the folate cycle genes, 53 patients of medical centre "Family source" with a miscarriage who had one or more spontaneous miscarriages and/or frozen/regressing pregnancies in the obstetric-gynecological history were examined. The control group 1 contained of 24 conditionally healthy women with a favorable obstetrical anamnesis (absence of spontaneous abortions, complications of pregnancies and childbirths). As a control group 2 was used comparison group from the study of SI "Institute of hereditary diseases of the NAMS of Ukraine" (Lviv) - 150 women of the Western region of Ukraine without complicated genetic and obstetric history who had two or more healthy children. All groups were similar in terms of basic demographic characteristics.

Results and conclusions. A significant percentage of women with low-functional alleles in one, several or all genes MTHFR, MTRR, MTR, was found $83 \%$ (44 of 53 studied women of main group). The genotype frequencies of these genes in patients with miscarriages were compared with population control groups from Ukraine. According to data from different regions of Ukraine, the mean frequency of low-functional polymorphic variants of gene MTHFR C677->T exceeds 50\% in the general women population. The relation/association of low-functional alleles of genes MTHFR, MTRR, MTR with disorders of various processes associated with the pregnancy course was considered.

Keywords: pregnancy, miscarriages, polymorphism in the folate-cycle genes, hyperhomocysteinemia, folic acid, metafolin. 